\title{
Competition between mussels at the rocky intertidal zone of La Lobería, Río Negro, Argentina
}

\author{
Lorena P. ARRIBAS ${ }^{1,4}$, María BAGUR ${ }^{1}$, Sabrina A. SORIA ${ }^{1}$, Jorge L. GUTIÉRREZ ${ }^{2,3} \&$ M. Gabriela \\ $\mathrm{PALOMO}^{1,3}$

\begin{abstract}
${ }^{1}$ Museo Argentino de Ciencias Naturales "Bernardino Rivadavia" (MACN-CONICET). Av. Ángel Gallardo 470, C1405DJR, Buenos Aires, Argentina. lorearribas@yahoo.com.ar. ${ }^{2}$ Facultad de Ciencias Exactas y Naturales \& CONICET, Universidad Nacional de Mar del Plata. Dean Funes 3350, B7602AYL, Mar del Plata, Argentina.

${ }^{3}$ Grupo de Investigación y Educación en Temas Ambientales (GrIETA), Mar del Plata, Argentina. ${ }^{4}$ Centro Nacional Patagónico (CENPAT-CONICET). Bv. Almirante Brown 2915, Puerto Madryn, Argentina.
\end{abstract}

\begin{abstract}
Competitive interactions between individuals from a single or different species can regulate population densities and individual growth. Two mussel species, Brachidontes rodriguezii and Perumytilus purpuratus coexist in the rocky intertidal zone of La Lobería, Río Negro Province, Argentina. The aim of this study was to analyse the effect of intra- and interspecific competition growth and mortality of both bivalve species. An experiment was conducted to evaluate the intra- and interspecific competition using asbestos cement plates of $10 \mathrm{x} 10 \mathrm{~cm}$ varying mussel densities. The width of $P$. purpuratus showed a significant increase in presence of $B$. rodriguezii. There also was a non-significant trend toward decreasing $B$. rodriguezii size with increasing density of conspecifics and when coexisting with $P$. purpuratus. Mortality of B. rodriguezii and $P$. purpuratus did not differ significantly among treatments. Limited supply of $P$. purpuratus larvae or local tidal conditions that differentially affect each species could be leading to weak competition between both mussel species, thus allowing their coexistence.
\end{abstract}

Key words: Competition, Intertidal, Mussels, Rocky shore. Southwestern Atlantic.

Resumen: Competencia entre mitílidos en el intermareal rocoso de La Lobería, Río Negro, Argentina. Las interacciones competitivas entre individuos de una misma o distintas especies pueden regular las densidades poblacionales y el crecimiento individual. Dos especies de mitílidos, Brachidontes rodriguezii y Perumytilus purpuratus, coexisten en el intermareal rocoso de La Lobería, provincia de Río Negro, Argentina. El objetivo de este trabajo fue analizar el efecto de la competencia intra- e interespecífica sobre el crecimiento y la mortalidad de ambas especies de bivalvos. Se realizó un experimento para evaluar la competencia intra- e interespecífica utilizando placas de fibrocemento de 10 x $10 \mathrm{~cm}$ variando las densidades de mitílidos. El ancho de $P$. purpuratus mostró un aumento significativo ante la presencia de $B$. rodriguezii. Se observó también una tendencia no significativa hacia la disminución de tallas de $B$. rodriguezii al aumentar la densidad de coespecíficos y al coexistir con $P$. purpuratus. La mortalidad de $B$. rodriguezii y $P$. purpuratus no mostró diferencias significativas entre tratamientos. Un limitado arribo de larvas de P. purpuratus o condiciones locales del intermareal que benefician diferencialmente a las especies podrían llevar a que los efectos de competencia entre estas sean débiles, haciendo posible la coexistencia.

Palabras clave: Competencia, Intermareal, Mejillines, Costa rocosa. Atlántico Sudoeste.

\section{INTRODUCTION}

Space is usually the main limiting resource for sessile organisms in rocky intertidal substrates (Branch, 1975; Bertness, 1989; Levinton, 2009). Crowding and interference among individuals of the same or different species often reduce individual survival, growth or reproductive success (Branch, 1975; Boaventura et al., 2002; Iveša et al., 2010; Quinn et al., 2012). When competition for space occurs between individuals of different species (i.e., interspecific competition), both species can coexist at a given spatial scale but have segregated distributions at finer scales (Rius \& McQuaid, 2006; Levinton, 2009). In such a case, the species with a higher rate of growth will be the most successful competitor for space (Levinton, 2009) causing negative impacts on the abundance, growth, and fine scale distribution of the competitively inferior species.

It is often found that competition for space 


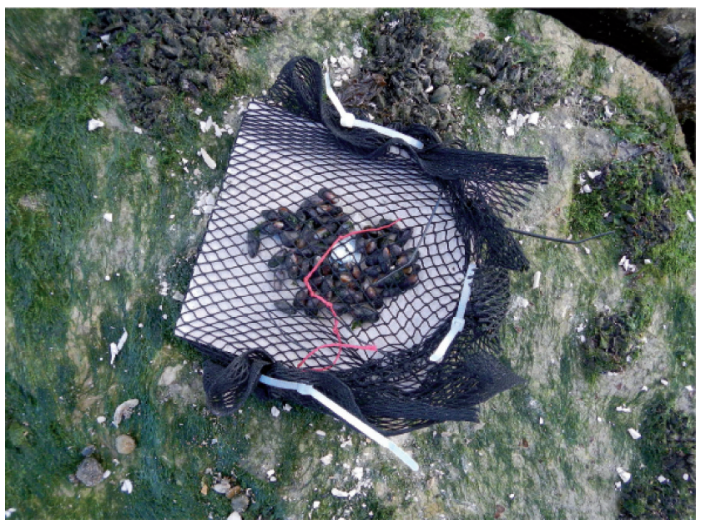

Fig. 1. Mussels in asbestos cement plates $(10 \times 10 \mathrm{~cm})$ on the rocky mid intertidal at La Lobería.

within a species (i.e., intraspecific competition) is much stronger than interspecific competition (Bertness, 1989; Boaventura et al., 2002). This is generally attributed to the fact that individuals of the same species tend to use spaces in a more similar way than individuals of different species (Firth \& Crowe, 2010; Quinn et al., 2012). Strong evidence in this regard was found for the limpet Patella vulgata Linnaeus, 1758, in Portugal (individual size and weight were more strongly affected by conspecifics than individuals from a second species; Boaventura et al., 2002). However, competition is a density-dependent process and the relative importance of interspecific and intraspecific effects will ultimately depend on the relative densities at which each species occurs (Boaventura et al., 2002; Rius \& McQuaid, 2009; Iveša et al., 2010). Furthermore, the strength of intraspecific or interspecific effects may not differ between species that are similar in morphology or other traits related to space occupancy and/or use.

The aim of this study was to analyze the effect of intra- and interspecific competition in the growth and mortality of the bivalves Brachidontes rodriguezii (d'Orbigny, 1846) and Perumytilus purpuratus (Lamarck, 1819). Either one or both of these species dominate the sessile invertebrate assemblages in rocky intertidal areas of the Northern Argentinean coast, with B. rodriguezii occurring from $32^{\circ} 10^{\prime}$ to $42^{\circ} 58^{\prime} \mathrm{S}$ (Rios, 2009; Trovant et al., 2013) and P. purpuratus occurring from $2^{\circ} 00^{\prime} \mathrm{S}-77^{\circ} 30^{\prime} \mathrm{W}$ to $41^{\circ} 8^{\prime} \mathrm{S}-63^{\circ} 10^{\prime} \mathrm{W}$ (Sánchez \& Zaixso, 1995; Prado \& Castilla, 2006; Rios, 2009; Trovant et al., 2015). Both species oc- cur in high densities at the mid intertidal zone —up to 200000 ind. $\mathrm{m}^{-2}$ of B. rodriguezii and 40 000 ind. $\mathrm{m}^{-2}$ of P. purpuratus - (Penchaszadeh, 1973; Arribas et al., 2013) and are very similar in their biology and morphology (Adami et al., 2013). Sites occurring along the range where both species coexist $\left(41^{\circ}\right.$ to $\left.43^{\circ} \mathrm{S}\right)$, provide a good opportunity to evaluate the importance of intra- and interspecific competition in regulating population densities and individual growth. We tested the hypothesis that the interaction among individuals of the same species and/or among individuals of different species generates changes in organism sizes and mortality.

\section{MATERIAL AND METHODS}

\section{Study area}

The experiment was conducted in the rocky intertidal zone of La Lobería, Río Negro province $\left(41^{\circ} 09^{\prime} \mathrm{S}-63^{\circ} 07^{\prime} \mathrm{W}\right)$, where both bivalve species coexist (Adami et al., 2004; Liuzzi \& López Gappa, 2008). This site is characterized by a macrotidal regime with high tides average of 4.41 meters, upper intertidal areas where gravel and sand accumulate, and a mid to low intertidal zone occupied by platforms made of consolidated sediments from the Río Negro formation (i.e., fine- to mid-grained sandstone with laminar to cross-bedded stratification and silty mudstones, Kokot et al., 2004).

\section{Sampling}

An experiment was conducted from March 2012 to March 2013 in the mid intertidal zone to test for competition between the two mussel species. The experimental design included treatments combining different densities of the two mussel species, which allowed simultaneously examine intra- and interspecific competition. The experimental mussels were collected from the mid intertidal zone, determined to species level, and measured. Then, they were kept in aerated seawater overnight to allow them to aggregate and regenerate their byssus. The experimental units consisted of plates $(10 \times 10 \mathrm{~cm})$, where mussels ranging 10-15 mm long were first covered with a $5 \mathrm{~mm}$ mesh to keep them firm in the plates until they have attached (Fig. 1). After 3 and 6 months meshes were loosened to minimize any potential mesh-induced restriction on mussel growth, but were still kept tied to the plates to help main- 

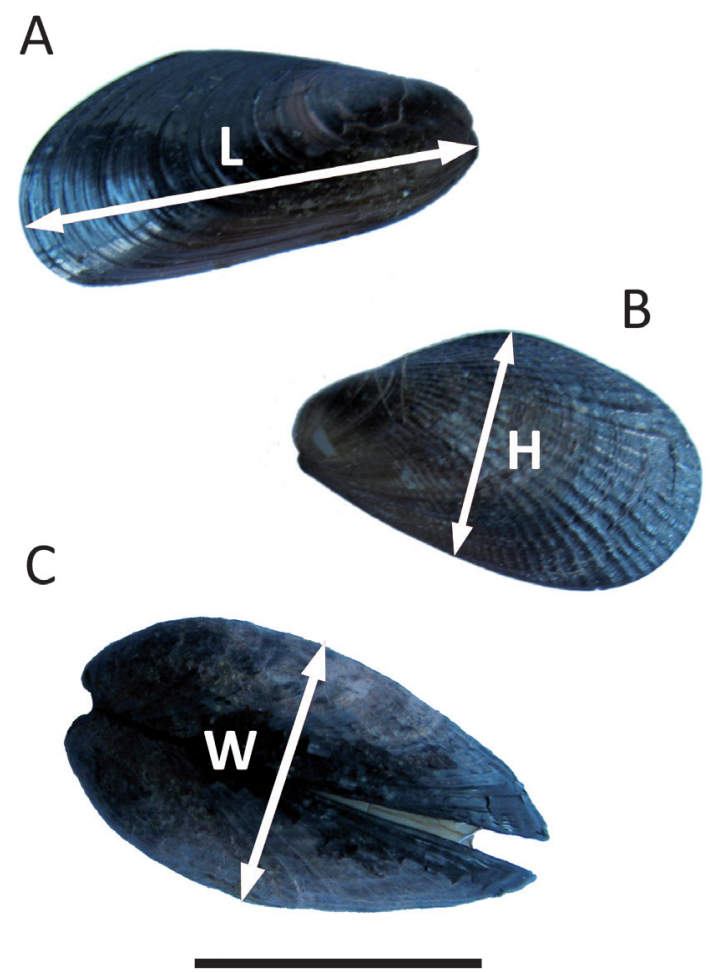

Fig. 2. Variables measured on both mussel species during the competition experiment ( $\mathrm{L}=$ length, $\mathrm{H}=$ height and $\mathrm{W}=$ width). A) Brachidontes rodriguezii. $\mathrm{B}$ and C) Perumytilus purpuratus. Scale bar: $10 \mathrm{~mm}$.

taining the mussels in place. Treatments are detailed on Table 1. The number of mussels in each treatment corresponds to the natural average density of mussels in the field, except for treatments with $25 \mathrm{~B}$. rodriguezii, which were added for comparison with natural $P$. purpuratus densities. Five replicates per treatment were positioned at random across two sites. Twelve months later, replicates were removed and taken to the laboratory where the final size and mortality (estimated from the number of empty articulated mussel shells in the plates) of $B$. rodriguezii and $P$. purpuratus were measured for each sampling unit. Three measures of mussel size were taken using a calliper $( \pm 0.01 \mathrm{~mm})$, length $(\mathrm{L})$, height (H) and width (W, Fig. 2), since not all measures can necessarily be affected by competition. The mean of these response variables was calculated for mussels in each plate both at the beginning and at the end of the experiment. Competition was identified by lower size increments or increased mortalities of mussels.
Table 1. Experimental design used to study intraand interspecific competition between mussels Brachidontes rodriguezii and Perumytilus purpuratus. The values in the cells indicate the number of mussels per plate. Natural densities used were 25 and 150 individuals per $100 \mathrm{~cm}^{2}$ for $P$. purpuratus and B. rodriguezii, respectively. Treatment 3 was eliminated from the analysis because of loss of several replicates.

\begin{tabular}{lccccc}
\hline \multicolumn{5}{c}{ Treatments } \\
\hline & 1 & 2 & 3 & 4 & 5 \\
\hline $\begin{array}{l}\text { Brachidontes } \\
\text { rodriguezii }\end{array}$ & 25 & 150 & 150 & 0 & 25 \\
$\begin{array}{l}\text { Perumytilus } \\
\text { purpuratus }\end{array}$ & 0 & 0 & 25 & 25 & 25 \\
\hline
\end{tabular}

\section{Data analysis}

Due to the loss of several replicates after 12 months, data was analysed only for one of the two experimental sites. One-way ANOVA was used to analyse size and mortality for $B$. rodriguezii data (treatments as fixed factor) and a t-Student test was used for P. purpuratus data. The treatment with $150 \mathrm{~B}$. rodriguezii-25 P. purpuratus was eliminated from the analysis (because of loss of several replicates) and only three replicates out of the original five were used. Homogeneity of variances was evaluated by Cochran's test, which was not significant in all cases. Due to the large loss of replicates, the statistical power (Tosta, 2013) of the tests (PE: percent statistical power) was calculated for size and mortality of $B$. rodriguezii and P. purpuratus.

\section{RESULTS}

Average length, height and width of Brachidontes rodriguezii shells did not differ significantly among treatments (Table 2, Fig. 3).

Perumytilus purpuratus width increments differed significantly between treatments (Table 3 ). The width of P. purpuratus was $19 \%$ higher in the 25 B. rodriguezii-25 P. purpuratus treatment than in the 25 P. purpuratus treatment (Fig. 3C). Differences between treatments in $P$. purpuratus length increments approached significance $(\mathrm{p}=$ $0.06)$ and the power of the test was low $(52.6 \%)$, which suggests that lack of significance in this case might be due to low sample size. $\mathrm{PE}$ percentages for $P$. purpuratus (Table 3) were an order of magnitude higher than those of $B$. rodriguezii (Table 2), which indicates that probability of incurring in Type II was lower in the analyses 

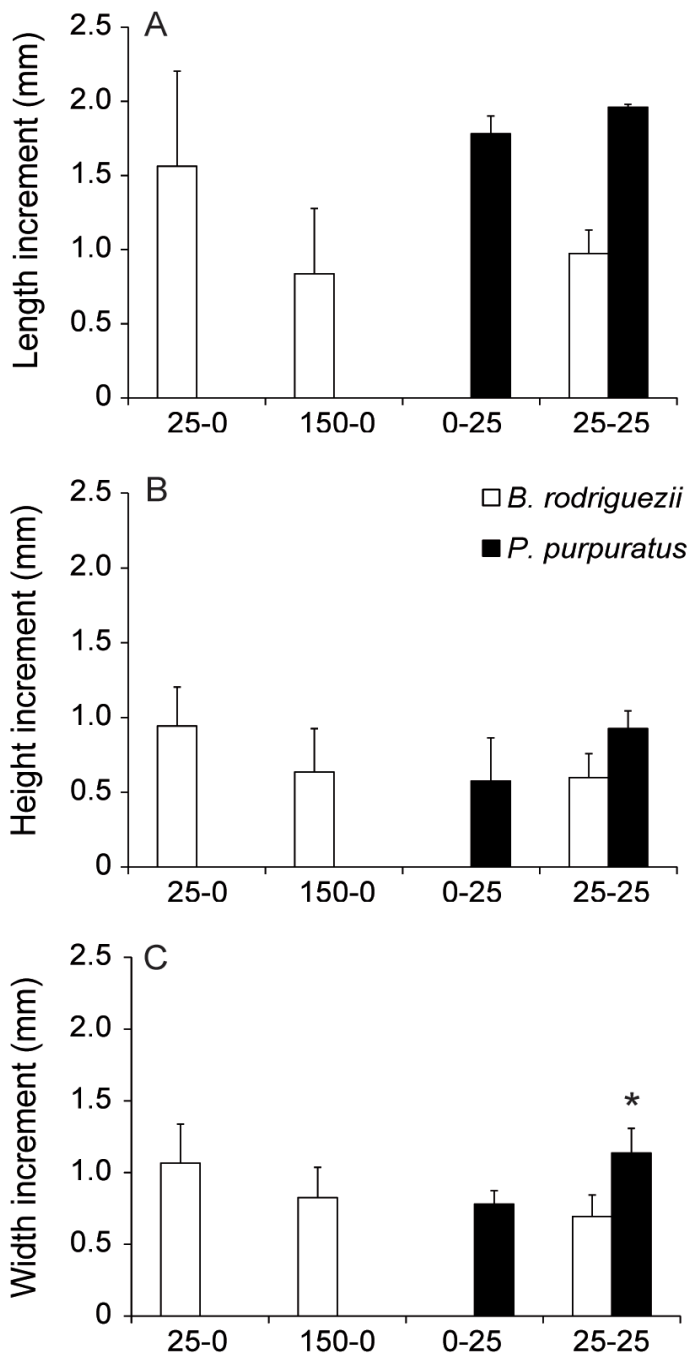

Fig. 3. Average increments $(\mathrm{mm} \pm \mathrm{SD})$ in the dimensions of mussel Brachidontes rodriguezii and Perumytilus purpuratus shells in the different density treatments (25-0, 150-0, 0-25 and $25-25$ per $10 \times 10 \mathrm{~cm}$ plate; see Table 1). A) Length increment, B) Height increment, C) Width increment. * Significant differences.

concerning $P$. purpuratus. Nonetheless, PE was still well below customary acceptable levels (i.e., 80\%) for P. purpuratus length and height.

Brachidontes rodriguezii percent mortality did not differ significantly among treatments (ANOVA, MS $=152.13, \mathrm{~F}_{2,6}=3.82, \mathrm{p}=0.085$, $\mathrm{PE}=100 \%$, Fig 4). Percent average mortality of P. purpuratus was similar between treatments (tStudent test $=-0.004, \mathrm{p}=0.996, \mathrm{PE}=5 \%$, Fig. 4 ).
Table 2. One-way ANOVA results on the length, height and width of Brachidontes rodriguezii after 12 months into the intra- and interspecific competition experiment. $\mathrm{PE}=$ percentage of the statistical power of the test. $p>0.05$ in all cases.

\begin{tabular}{lllll} 
& \multicolumn{4}{c}{ Brachidontes rodriguezii } \\
\hline df & MS & F & p & PE (\%)
\end{tabular}

\begin{tabular}{llllll}
\hline Length & & & & & \\
Treatments & 2 & 0.44 & 2.11 & 0.21 & 9.40 \\
Residual & 6 & 0.21 & & & \\
Height & & & & & \\
Treatments & 2 & 0.11 & 1.82 & 0.24 & 6.00 \\
Residual & 6 & 0.06 & & & \\
Width & & & & & \\
Treatments & 2 & 0.11 & 2.28 & 0.18 & 6.03 \\
Residual & 6 & 0.05 & & & \\
\hline
\end{tabular}

\section{DISCUSSION}

A high population density may facilitate survival by protecting against physical and biological disturbances, but at the expenses of individual growth rates that would decrease in densitydependent fashions (Bertness, 1989). Here we observed a significant increase in the width of Perumytilus purpuratus when co-occurring with an equal number of individuals of Brachidontes rodriguezii. There also was a non-significant trend toward decreasing $B$. rodriguezii size with increasing density of conspecifics and when coexisting with $P$. purpuratus. It seems that growth of $P$. purpuratus is benefited by the presence of $B$. rodriguezii. On the southern coast of South Africa the mussel Perna perna increases survival of Mytilus galloprovincialis in the low intertidal, generating protection against wave action (Rius \& McQuaid, 2006). The presence of B. rodriguezii could be ameliorating abiotic conditions or hydrodynamic factors that enhance mussel attachment (Gutiérrez et al., 2015) and growth.

This study was conducted near the Northern limit of distribution of $P$. purpuratus. In the rocky intertidal zone of La Lobería the natural density of $B$. rodriguezii adults is higher than $P$. purpuratus (Arribas et al., 2013). This difference in mussel densities may be due to environmental variables (e.g., climate, currents), and/or recruitment (Sánchez \& Zaixso, 1995; Rius \& McQuaid, 2006; Firth \& Crowe, 2010). Climate influences the distribution range of the mussels since $B$. ro- 


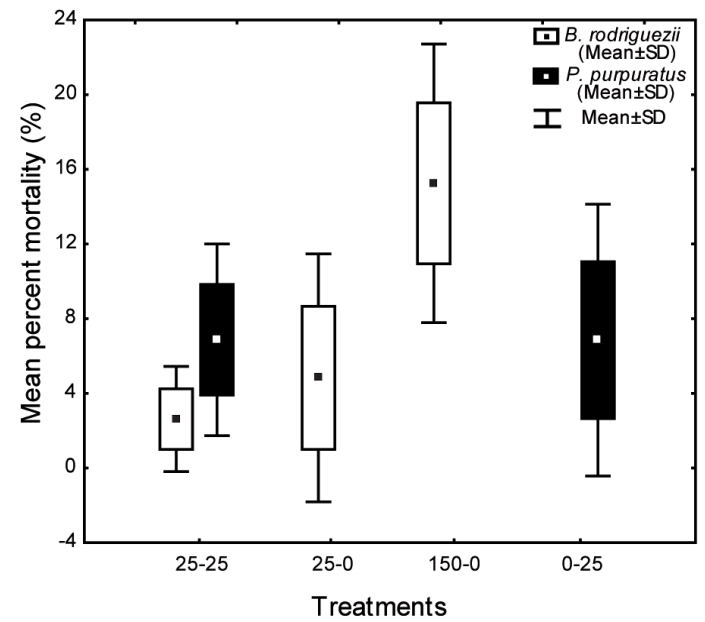

Fig. 4. Mean percent mortality (\% \pm SD) of the mussels Brachidontes rodriguezii and Perumytilus purpuratus in the different individual density treatments (25-25, 25-0, 150-0 and 0-25 per $10 \times 10 \mathrm{~cm}$ plate; see Table 1 ).

driguezii is restricted to the warm-temperate biogeographical region (Acha et al., 2004; Balech \& Ehrlich, 2008) and P. purpuratus occurs in coldtemperate region (Adami et al., 2013). Density of mussels also changes with latitude, being $P$. purpuratus less abundant towards the northern limit of its distribution (Ringuelet et al., 1962; Adami et al., 2013; Arribas et al., 2013; Trovant et al., 2013). Moreover, competitive interactions might reduce the abundance of species in their geographical distribution limit, since mussel growth and space limitation produce an increase in adult mortality (Boaventura et al., 2002; Rius \& McQuaid, 2009). However, no negative effects of $B$. rodriguezii on $P$. purpuratus were observed in mortality or size, while a width increase of the $P$. purpuratus shells was found in the presence of $B$. rodriguezii. Therefore, the low population density of $P$. purpuratus is probably not a result from competition with $B$. rodriguezii, but perhaps from a low larval supply.

Intra- and interspecific competition account for increased mortality with increasing population densities (Bertness, 1989; Boaventura et al., 2002). In this study, mussel species mortality did not differ significantly among treatments. Statistical power was maximum (100\%) when testing for $B$. rodriguezii mortality, which indicates that the probability of incurring in a false negative (i.e., the probability of not rejecting a null hypothesis that is true) is negligible. This is because variability between replicates was high (Fig. 4), particularly in the treatment with
Table 3. Student-t results on the length, height and width of mussel Perumytilus purpuratus after 12 months into the intra- and interspecific competition experiment. $\mathrm{PE}=$ percentage of the statistical power of the test. $* \mathrm{p}<0.05$.

\begin{tabular}{lccc}
\cline { 2 - 4 } & \multicolumn{3}{c}{ Perumytilus purpuratus } \\
\hline Length & $\mathrm{t}$ & $\mathrm{p}$ & $\mathrm{PE}(\%)$ \\
Height & -2.54 & 0.06 & 52.6 \\
Width & -1.95 & 0.12 & 36.5 \\
\hline
\end{tabular}

150 B. rodriguezii. The presence of both species would thus not be affecting the survival of the other species, and mortality could have been caused by external factors. Environmental heterogeneity (e.g., higher concentration of algae and/ or sediment) or the clogging of the nets attached to maintain the mussels in the plates could have contributed to variation the mortality of individuals among replicates.

In this study, variations were observed under an interspecific competition experimental design, but we were unable to make comparisons between sites or with the $150 \mathrm{~B}$. rodriguezii-25 P. purpuratus treatment due to loss of replicates. One of the biggest problems when performing field experiments is the inability to control environmental variables that could generate loss of replicates. This often makes samples no longer representative and calculations partial. The degree to which a sample is biased, is the degree to which one can over- or underestimate the actual value of the parameter to be measured (Underwood, 1997). Accounting for Type II error and the statistical power of the test is very important because it represents the probability of not rejecting the null hypothesis when it is false (Underwood, 1997; Zar, 2010). In most of our non-significant tests, the statistical power was low, which indicates that our conclusions need to be considered with caution. The only exception was the lack of significant differences in B. rodriguezii mortality across treatments.

\section{CONCLUSION}

The results of this study suggest that the presence of $B$. rodriguezii leads to width increases in $P$. purpuratus. The population density of both species appears to be primarily regulated by larval supply or local conditions that benefit one species over the other (Boaventura et al., 2002; 
Arribas et al., 2015). Low P. purpuratus densities in its northern limit of distribution are perhaps due to unfavourable environmental conditions. This would lead to weak competitive effects of $P$. purpuratus on $B$. rodriguezii. Due to the loss of replicates, the results of this study should be taken as preliminary.

\section{AKNOWLEDGEMENTS}

We thank Guido Pastorino for help in the taxonomic identification of mytilids and Carlos Sanchez Antelo for field assistance. This research was partly funded by CONICET (Consejo Nacional de Investigaciones Científicas y Técnicas, Argentina; PIP 112-200801-00732 to MGP) and funds of the foundation SARCE (South American Research Group on Coastal Ecosystems). MB and LPA had the support of CONICET PhD scholarships. This is a contribution to GrIETA program. This manuscript was substantially improved by comments from anonymous reviewers.

\section{BIBLIOGRAPHY}

Acha, E.M., H. Mianzan, R. Guerrero, M. Favero \& J. Bava. 2004. Marine fronts at the continental shelves of austral South America: physical and ecological processes. Journal of Marine Systems 44: 83-105.

Adami, M.L., A. Tablado \& J. López Gappa. 2004. Spatial and temporal variability in intertidal assemblages dominated by the mussel Brachidontes rodriguezii (d’Orbigny, 1846). Hydrobiologia 520: 49-59.

Adami, M.L., G. Pastorino \& J.M. Orensanz. 2013. Phenotypic differentiation of ecologically significant Brachidontes species co-occurring in intertidal mussel beds from the southwestern Atlantic. Malacologia 56(1-2): 59-67.

Arribas, L.P., M. Bagur, E. Klein, P. Penchaszadeh \& M.G. Palomo. 2013. Geographic distribution of mussel species and associated assemblages along the northern Argentinean coast. Aquatic Biology 18: $91-103$.

Arribas, L.P., M. Bagur, J.L. Gutiérrez \& M.G. Palomo. 2015. Matching spatial scales of variation in mussel recruitment and adult densities across southwestern Atlantic rocky shores. Journal of Sea Research 95: 16-21.

Balech, E. \& M.D. Ehrlich. 2008. Esquema biogeográfico del Mar Argentino. Revista de Investigación y Desarrollo Pesquero 19: 45-75.

Bertness, M.D. 1989. Intraspecific competition and facilitation in northern acorn barnacles. Ecology 70 : 257-268.

Boaventura, D., L. Cancela da Fonseca \& S.J. Hawkins. 2002. Analysis of competitive interactions between the limpets Patella depressa Pennant and Patella vulgata L. on the northern coast of Portugal. Journal of Experimental Marine Biology and Ecology 271: 171-188.

Branch, G.M. 1975. Mechanisms reducing intraspecific competition in Patella spp.: migration, differentiation and territorial behavior. Journal of Animal Ecology 44 (2): 575-600.

Firth, L.B. \& T.P. Crowe. 2010. Competition and habitat suitability: small-scale segregation underpins large-scale coexistence of key species on temperate rocky shores. Oecologia 162: 163-174.

Gutiérrez, J.L., M.G. Palomo, M. Bagur, L.P. Arribas \& S.A. Soria. 2015. Wave action limits crowding in an intertidal mussel. Marine Ecology Progress Series 518: 153-163.

Iveša, L., M.G. Chapman, A.J. Underwood \& R.J. Murphy. 2010. Differential patterns of distribution of limpets on intertidal seawalls: experimental investigation of the roles of recruitment, survival and competition. Marine Ecology Progress Series 407: 55-69.

Kokot, R.R., J.O. Codignotto \& M. Elissondo. 2004. Vulnerabilidad al ascenso del nivel del mar en la costa de la provincia de Río Negro. Revista de la Asociación Geológica Argentina 59(3): 477-487.

Levinton, J.S. 2009. Marine biology: function, biodiversity, ecology. 3rd ed. Oxford University Press, Inc., Oxford, 588 pp.

Liuzzi, M.G. \& J. López Gappa. 2008. Macrofaunal assemblages associated with coralline turf: species turnover and changes in structure at different spatial scales. Marine Ecology Progress Series 363: 147-156.

Penchaszadeh, P.E. 1973. Ecología de la comunidad del mejillón (Brachydontes rodriguezi d'Orb.) en el medio litoral rocoso de Mar del Plata (Argentina). El proceso de recolonización. Physis 32(84): 51-64.

Prado, L. \& J.C. Castilla. 2006. The bioengineer Perumytilus purpuratus (Mollusca: Bivalvia) in central Chile: biodiversity, habitat structural complexity and environmental heterogeneity. Journal of the Marine Biological Association of the United Kingdom 86: 417-421.

Quinn, B.K., M.R. Boudreau \& D.J Hamilton. 2012. Inter- and intraspecific interactions among green crabs (Carcinus maenas) and whelks (Nucella lapillus) foraging on blue mussels (Mytilus edulis). Journal of Experimental Marine Biology and Ecology 412: 117-125.

Ringuelet, R.A., A. Amor, N. Magaldi \& R. Pallares. 1962. Estudio ecológico de la fauna intercotidal de Puerto Deseado, en febrero de 1961 (Santa Cruz, Argentina). Physis 23: 35-53.

Rios, E.C. 2009. Compendium of Brazilian sea shells. Rio Grande, R.S.: Evangraf, 676 pp.

Rius, M. \& C.D. McQuaid. 2006. Wave action and competitive interaction between the invasive mussel Mytilus galloprovincialis and the indigenous Perna perna in South Africa. Marine Biology 150: 69-78.

Rius, M. \& C.D. McQuaid. 2009. Facilitation and competition between invasive and indigenous mus- 
sels over a gradient of physical stress. Basic and Applied Ecology 10: 607-613.

Sánchez, V. \& H.E. Zaixso. 1995. Secuencias de recolonización mesolitoral en una costa rocosa del golfo San José (Chubut, Argentina). Naturalia Patagónica, Serie Ciencias Biológicas 3(1-2): 57-83.

Tosta, M.R. 2013. El poder estadístico. Diferencias observadas cuando se cambia el alfa establecido en un estudio de investigación. Scientific International Journal 10(1): 23-32.

Trovant, B., D.E. Ruzzante, N.G. Basso \& J.M. Orensanz. 2013. Distinctness, phylogenetic relations and biogeography of intertidal mussels (Brachidontes, Mytilidae) from the south-western Atlantic. Journal of the Marine Biological Association of the
United Kingdom 93(7): 1843-1855.

Trovant, B., J.M. Orensanz, D.E. Ruzzante, W. Stotz \& N.G. Basso. 2015. Scorched mussels (Bivalvia: Mytilidae: Brachidontinae) from the temperate coasts of South America: Phylogenetic relationships, trans-Pacific connections and the footprints of Quaternary glaciations. Molecular Phylogenetics and Evolution 82: 60-74.

Underwood, A.J. 1997. Experiments in ecology: their logical design and interpretation using analysis of variance. Cambridge University Press, Cambridge, 504 pp.

Zar, J.H. 2010. Biostatistical analysis. 5th ed. Prentice Hall, New Jersey, 944 pp.

Recibido: 16-VIII-2015

Aceptado: 10-V-2016 